\title{
Forest ecosystem management in North America: From theory to practice
}

\author{
by Cynthia Patry ${ }^{1, *}$, Daniel Kneeshaw ${ }^{1}$, Stephen Wyatt², Frank Grenon ${ }^{3}$ and Christian Messier ${ }^{4}$
}

\begin{abstract}
Forest ecosystem management (EM) in North America has evolved from a theoretical concept to operational practice over the last two decades, but its implementation varies greatly among regions. This paper attempts to evaluate (1) if and how emulation of natural disturbances (END) is being used as a conceptual bases for implementing EM, and more particularly, what strategies are used to define the natural forest of reference, and (2) what temporal and spatial scale strategies are being considered for seven important retention elements (downed woody debris, snags, green trees, corridors, riparian buffers, large patches and old forest)? To conduct this evaluation, five guides from four geographically well-distributed regions in North America are compared. Although END is the central conceptual foundation underlying four of the five guides, a natural forest of reference is not always clearly identified and none of the guides consider future impacts due to global change. The major weakness common to all five guides is the lack of consideration of long-term forest dynamics, particularly the lack of clear strategies for retention elements at a temporal scale longer than a single rotation. Generally, the spatial scales chosen for retention elements are not well-justified ecologically and targets for each retention element are not identified at different spatial scales. We stress that strong efforts have been made to develop forest management that incorporates some elements of natural variability and which considers societal needs, but further improvements are required. We conclude by presenting some suggestions to improve the approach. For example, creating more realistic guidelines in integrating current and future forest dynamics with pre-settlement information and planning rotation lengths that are inspired by the dominant natural disturbance.
\end{abstract}

Keywords: forest ecosystem management, implementation, North America, retention strategies and emulation of natural disturbances, spatiotemporal scales

\section{RÉSUMÉ}

Laménagement écosystémique des forêts en Amérique du Nord est passé d’un concept théorique à une application opérationnelle au cours des deux dernières décennies. Par contre, sa mise en œuvre varie grandement selon les régions. Cet article tente dévaluer d’une part (2) si lémulation des perturbations naturelles (END) a été utilisée comme un concept de base pour la mise en œuvre de laménagement écosystémique, et si oui, quelles stratégies ont été utilisées pour définir la forêt de référence et (2) quelles échelles temporelles et spatiales ont été considérées dans les stratégies concernant sept éléments de rétention (bois mort au sol, chicots, arbres vivants, corridors, bandes riveraines, larges îlots et vieilles forêts)? Pour ce faire, cinq guides en aménagement écosystémique issues de quatre régions géographiquement bien distribuées ont été comparés. Bien qu'END soit central dans quatre guides sur cinq, la forêt de référence nest pas toujours clairement définie. De plus, aucun des guides ne considère les impacts futurs induits par les changements globaux. La faiblesse majeure commune à tous les guides est le manque de considération pour les dynamiques à long terme de la forêt, particulièrement le manque de stratégies claires concernant le maintien de certains éléments de rétention sur plus d’une rotation. Généralement, les échelles spatiales choisies pour la rétention ne sont pas bien justifiées écologiquement et les cibles de rétention pour chacun des éléments ne sont pas proposées à plusieurs échelles spatiales. Nous concluons que des efforts considérables ont été faits afin de concevoir des aménagements qui tentent de recréer la variabilité naturelle tout en considérant les besoins sociaux, toutefois, des améliorations sont encore requises. Nous terminons larticle en présentant des suggestions afin d’améliorer les stratégies analysées. Par exemple, intégrer les connaissances sur la dynamique des forêts avant colonisation, actuelles et futures afin de créer des lignes directrices plus réalistes concernant la forêt de référence, ainsi que planifier la durée des rotations inspirée par la perturbation naturelle dominante.

Mots clés : aménagement forestier écosystémique, mise en œuvre, Amérique du Nord, stratégies de rétention et émulation des perturbations naturelles, échelles spatio-temporelles

\footnotetext{
${ }^{1}$ Université du Québec à Montréal, Centre détude de la forêt (CEF), Département des sciences biologiques, Case postale 8888, Succursale Centreville, Montréal (Québec) H3C 3P8.

${ }^{2}$ Faculté de foresterie, Université de Moncton Campus Edmundston, 165, boulevard Hébert, Edmundston (Nouveau-Brunswick) E3V 2 S8.

${ }^{3}$ Centre denseignement et de recherche en foresterie de Sainte-Foy inc. (CERFO), 2424, chemin, Sainte-Foy, Québec (Québec) G1V $1 T 2$.

${ }^{4}$ Université du Québec en Outaouais (UQO), Institut des Sciences de la Forêt Tempérée (ISFORT) et Centre deetude de la forêt, Ripon (Québec) J0V1V0.

*Corresponding author. E-mail: patry.cynthia@courrier.uqam.ca.
} 


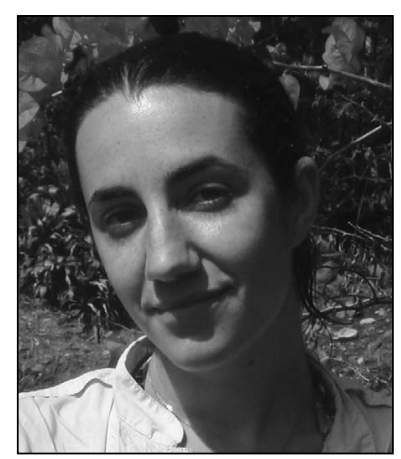

Cynthia Patry

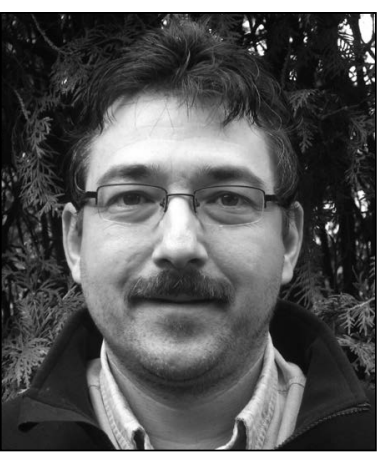

Christian Messier

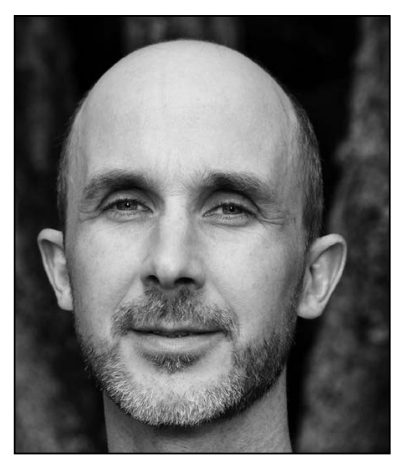

Daniel Kneeshaw

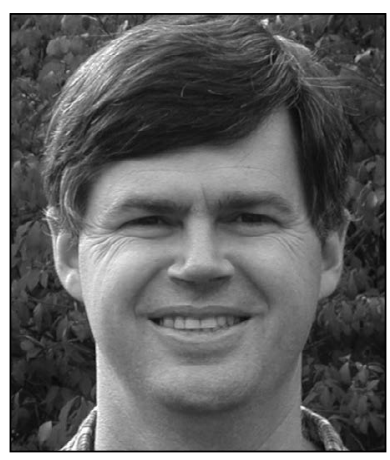

Stephen Wyatt

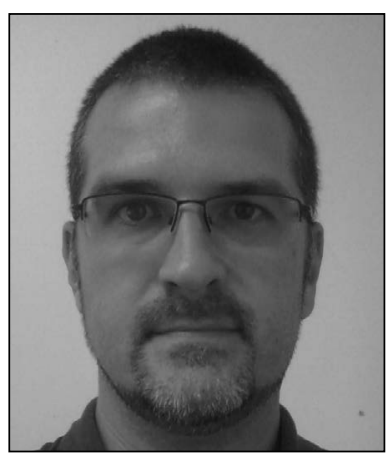

Frank Grenon

\section{Background Information}

In the early 1990s, the United States Department of Agriculture (USDA) Forest Service and the Department of the Interior Bureau of Land Management (BLM), were among the first in North America to officially adopt ecosystem management (EM) as the exclusive means of managing national forests (Butler and Koontz 2005). Shortly afterward, Grumbine (1994) attempted to provide a working definition of EM. He described EM as the interface between scientific knowledge about ecosystems and the management of socio-political values, with the goal of protecting natural ecosystem integrity over the long term. Since that time, many organizations throughout the world, ranging from local private owners to state governments, have begun endorsing and applying this approach to sustainable forest management. Many government organizations have developed sophisticated guidelines for EM (e.g., Archibald et al. 1997). Yet, the application of EM varies greatly from one region to another. We believe this is partly due to the vague theoretical foundations underpinning EM and its application to forestry, which leads to wide variation in its implementation (Rauscher et al. 2000). This situation has created a growing interest in comparing the diversity of implementation strategies and their links with scientific ecological knowledge.

In parallel with the developing interest in EM, Hunter (1993) proposed an operational solution for maintaining ecosystem integrity. He suggested that forest management that "emulates natural disturbances" (END) could maintain or recreate the natural variability encountered in natural or semi-natural forest ecosystems. The main assumption of END is that the various organisms normally present in these ecosystems are adapted to the range of natural variation in time and space that is created by natural disturbances. The use of END can also be viewed as a coarse-filter approach to ecosystem management (Armstrong et al. 2003). In North America, the idea of emulating natural disturbances was quickly integrated into EM (Dale et al. 1998, Work et al. 2004, Gauthier et al. 2008).
Despite the scientific interest in using END for management purposes, its implementation presents many obstacles. First, forest management that is based on END requires knowledge of the natural range of variability (Landres et al. 1999) under past disturbance regimes and the current state of the forest. Thus, information regarding variation in the size, intensity and frequency of past natural disturbances is required. Such information is often difficult to obtain, thereby limiting the application of the END approach in many cases, such as over much of Europe and Asia (Berry et al. 1998). Second, a further challenge requires that the time period used to characterize the forest of reference be determined. Although the time period generally focuses on pre-settlement forest conditions (Wallin et al. 1996, Hessburg et al. 2005), no consensus has emerged to date regarding what period should be used. Third, given that the effects of global change are expected to alter forest ecosystems, a debate is growing regarding the usefulness of emulating past conditions as guiding principles for establishing and maintaining future forests (Klenk et al. 2009). An additional argument against the strict implementation of END revolves around the difficulty in attaining social acceptability when emulating the extremes of the natural range of variability. For example, the creation of large aggregate cut blocks incorporating various forms of retention that emulate large fires in boreal forests may not be acceptable to some groups within the wider population (Kimmins 2004).

Retention ${ }^{1}$ is an important aspect of END since most natural disturbances rarely can ever completely reinitiate large areas and never remove as much biomass as conventional harvesting. For example, fire leaves a mosaic of patches that have been burnt to a greater or lesser degree (Bergeron $e t$ al. 2002). In addition, under most disturbance regimes, retention is maintained for a much longer period of time than under classic cutting rotations of less than 100 years. This induces a variety of spatiotemporal patterns for different retention elements. For this review, we focus on the spatiotemporal characteristics of seven key elements of retention: downed woody debris (DWD), snags, individual or patches of green trees, forested corridors, riparian buffers, old forest, and large forest patches. These are the elements that appear most frequently in the scientific literature, with a variety of strategies

${ }^{1}$ We have defined retention in this paper as any "natural feature that is maintained at one or different spatial scales and which will be maintained for a certain time in the forest matrix after harvesting or natural disturbances". 
being proposed. Establishing protected areas $^{2}$ is, of course, also an important strategy for retention and we treat this separately.

The natural variability of many retention elements was reduced following the arrival of industrial forestry. Forest management homogenizes many structural elements in the forest and has driven some elements beyond their natural range of variability (Cissel et al. 1999, Cyr et al. 2009). A review of the literature regarding the impacts of forest management on biodiversity reveals that the loss of old-forest attributes (Noss 1999, Hanski 2000, Gauthier et al. 2008) and increased forest fragmentation (Andren 1994, Etheridge et al. 2006) are among the most critical factors. The lack of large coarse woody debris following harvest also threatens the persistence of many saproxylic insects (Jonsson et al. 2005), cavity-nesting birds (Darveau and Desrochers 2001, Drapeau and Imbeau 2006), cryptogams, and fungi (Crites and Dale 1998).

The creation of large and numerous protected areas has been proposed as a solution to these issues. However, it is now recognized that the amount of forest that would be protected is likely to be insufficient for maintaining forest biodiversity (Heller and Zavaleta 2009, Wiersma and Nudds 2009). Nowadays, 92\% of the world's forests are outside of protected areas (Commonwealth of Australia 1999, cited by Lindenmayer et al. 2006). As a consequence, particular attention must be focused on the managed forest matrix and on the connectivity between protected areas and other retention elements (Lindenmayer and Franklin 2002). Connectivity is critical for many animal and plant species which are adapted to continuous forest cover (Franklin 1993, Lindenmayer 2000, Bennett 2003, Rosenvald and Lohmus 2008). Forests have been historically less fragmented in many regions than they are today (Wedeles and Sleep 2008).

Another important element to consider for successful implementation of EM is the maintenance of forest resilience. This is particularly important today due to rapid socio-ecological changes that are occurring worldwide. We define resilience as the capacity of a system to absorb and/or adapt to disturbance so as to persist in time (adapted from (Holling 1973). A resilient forest ecosystem greatly depends on the maintenance of functional diversity and important ecological processes across scales (Gunderson 2000). Because biodiversity and many ecological processes are affected by management that homogenizes forest structure, causes fragmentation, and reduces DWD and areas of old forests, we urgently need new management strategies that will maintain resilience. Although many key elements are needed to ensure a resilient forest, the retention of structural elements at both stand- and landscape-levels is crucial (Lindenmayer et al. 2012). These retention elements may also act as 凶temporal lifeboats" for biodiversity (Vanha-Majamaa and Jalonen 2001), meaning that these elements need to be planned over the long term (Landres et al. 1999). Fig. 1 illustrates the management suggested by literature regarding the seven retention elements and protected areas across temporal and spatial scales.

Since EM is proposed as a way of ensuring long-term forest functioning and maintenance of biodiversity, the main

\footnotetext{
${ }^{2}$ The designation of protected areas in guides matched the definition that was provided by Wiersma et al. (2010): "Geographic space clearly defined, recognized, dedicated and managed, through effective means, legal or otherwise, to ensure long-term conservation of nature and ecosystem services and cultural values associated with it."
}

objective of this paper is to critically review how EM is being implemented in four different regions of North America. Social and economic issues are important in EM (Bengston 1994, Grumbine 1994), but our analysis focuses on END and the spatiotemporal requirements for the aforementioned retention elements. We examined implementation guidelines in each of four regions, asking the following questions:

1) Is END used as one of the conceptual bases to implement $\mathrm{EM}$, and if so, what strategies are used to define the natural forest of reference?

2) Since legacy elements are important for ecological processes and biodiversity, are the temporal and spatial scales proposed for retention elements appropriate to achieve EM objectives?

\section{Methods}

For the comparison, we selected four regions that are widely distributed across North America to get a representative sample of different approaches being used in different forested ecosystems. These four regions represent different types of forests, disturbance regimes, and administrative organizations, but they all contain publicly owned forests. The regions are the Pacific Coast of the United States, the Pacific Coast of Canada, central Canada, and Atlantic Canada. Our choice was also based on the chronological date of EM adoption, from the earliest region being the US Pacific Coast in 1994 to the most recent being the Bay of Fundy (New Brunswick) in 2005. Each region defined its EM strategy in various guides, plans, or handbooks. We analyzed five different guides: two distinctive approaches for the Pacific Canadian Coast (governmental and non-governmental) and one for each of the other regions. In Table 1, the title and acronym, authors, reference, location, land tenure and complementary documents are presented for each guide. With some exceptions, guides are not stand-alone documents and are complemented by other guides (Table 1) or legislation (data not shown).

As a first step to answering our two questions, we reviewed the literature for key concepts of END and retention elements in forests, and prepared sets of keywords to be used for each of our questions. The first keyword list contained terms referring to the emulation of natural disturbances and included terms such as "mimic", "emulate", "recreate", and "forest of reference", among others. The second list consisted of the seven retention elements and their synonyms (examples of synonyms in parentheses) that are most commonly discussed in the literature: downed coarse woody debris, snags (e.g., cavity trees), green trees (e.g., variable retention), corridors (e.g., leave strips), riparian buffers (e.g., riparian reserve), large forest patches and old forest (e.g., over-mature forest).

In the second step, we searched electronic copies of the five guides, identifying text dealing with each keyword or synonym from the two keyword lists. The presence of the keywords in sub-titles or in the text led to the associated paragraphs or section being identified with a code based on the keyword. In some cases, a single section included two (or more) keywords and, therefore, was coded for both elements. Sections of the text lacking keywords were not coded.

In the third step, we used two different sets of criteria to analyze the text coded for END and the text coded for the seven retention elements. The four criteria used for analyzing each portion of the text that was coded for END were the following: emulation of natural disturbance or not, the temporal period of 

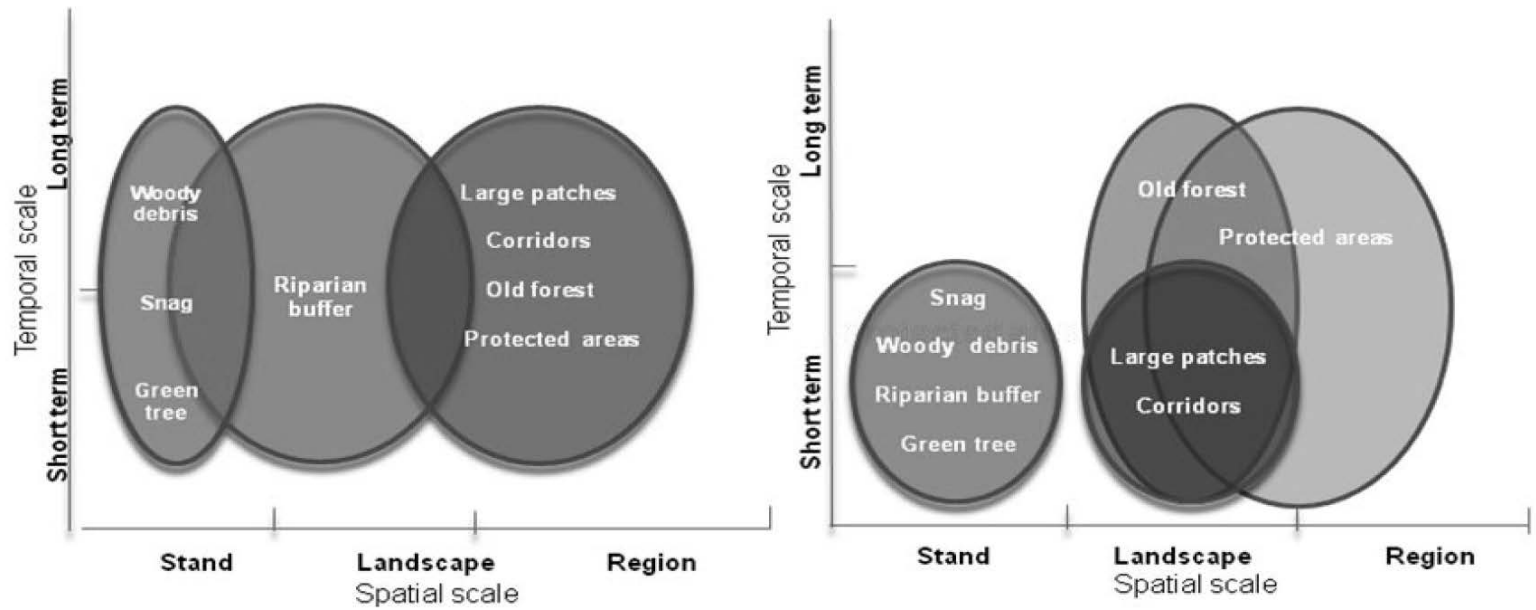

Fig. 1. The figure on the left visually expresses the main spatiotemporal theoretical objectives concerning retention elements, contrary the figure on the right that visually expresses a summary of the main spatiotemporal strategies used to maintain retention elements in the five guides. The $x$ axis shows the three spatial scales and the $y$ axis shows the two temporal scales considered. The order of elements within a sphere does not matter; it is the delimitation of a sphere that counts. The figure on the right is a generalization of the five guides, some exceptions occur (see Table ?).

Table 1. Document title authors, location, land tenure and additional documents of the five chosen guides relevant to the four regions

NDPE Document title Authors and reference Location Land tenure Additional documents

GFE Document title

Authors and reference Location

Land tenure

Additional documents

BG Document title Authors and reference Location

Land tenure

Additional documents

CIT Document title

guide Authors and reference

Location

Land tenure

Additional documents

NWFP Document title

Authors and reference

Location

Land tenure

Additional documents
Forest Management Guide for Natural Disturbance Pattern Emulation (NDPE)

Ontario Ministry of Natural Resources (OMNR 2001)

Ontario: Boreal and the Great Lakes-St. Lawrence Forest

Provincial public forest

Ontario's Living Legacy, among others

A new version of the guide now exists.

Forest management guidelines to protect native biodiversity in the Greater Fundy Ecosystem, 2nd edition (GFE)

Greater Fundy Ecosystem Research Group (Betts and Forbes 2005)

New Brunswick: Fundy Model Forest watershed

Federal public forest and private forest

Best Management Practices: A Practical Guide for New Brunswick's Private Woodlots

Biodiversity Guidebook - Forest Practices Code of British Columbia (BG)

Ministry of Forests and Range of British Columbia (Province of British Columbia 1995)

British Columbia

Provincial public forest

Riparian Management Area Guidebook and the Managing Identified Wildlife Guidebook, among others

Ecosystem-based management planning handbook (CIT)

Coast Information Team (Coast Information Team 2004)

British Columbia: Central and North Coast and Haida Gwaii

First Nations territories and public provincial forest

Hydroriparian Planning Guide, The Scientific Basis of Ecosystem-based Management, BC Protected Areas Strategy, among others.

Northwest Forest Plan: Standards and Guidelines for Management of Habitat for Late-Successional and Old-Growth Forest Related Species Within the Range of the Northern Spotted Owl (NWFP)

USDA Forest Service and the USDI Bureau of Land Management (USDA and USDI 1994)

Range of the northern spotted owl in Washington, Oregon, and northern California

Federal forest

Record of decision for Amendments to Forest Service and Bureau of Land Management Planning Documents Within the Range of the Northern Spotted Owl 
Table 2. Temporal and spatial requirements for each retention element in each guide

\begin{tabular}{|c|c|c|c|c|c|c|}
\hline $\begin{array}{l}\text { Retention } \\
\text { element }\end{array}$ & Scale & NDPE & GFE & BG & CIT guide & NWFP \\
\hline \multirow[t]{2}{*}{ DWD } & Temporal & $\begin{array}{l}\text { Ensuring } \\
\text { recruitment }\end{array}$ & $\begin{array}{c}\text { Ensuring } \\
\text { recruitment }\end{array}$ & Not all permanent & No detailed strategy & Ensuring recruitment \\
\hline & Spatial & Stand & Stand & Stand & Stand & Landscape \\
\hline \multirow[t]{2}{*}{ Snag } & Temporal & Not mentioned & $\begin{array}{l}\text { Ensuring } \\
\text { recruitment }\end{array}$ & $\begin{array}{c}\text { Ensuring } \\
\text { recruitment }\end{array}$ & No detailed strategy & Ensuring recruitment \\
\hline & Spatial & Stand & Stand & Stand & Stand & Stand \\
\hline $\begin{array}{l}\text { Green } \\
\text { tree }\end{array}$ & $\begin{array}{l}\text { Temporal } \\
\text { Spatial }\end{array}$ & $\begin{array}{l}\text { Not all permanent } \\
\text { Stand }\end{array}$ & $\begin{array}{l}\text { Not mentioned } \\
\text { Stand }\end{array}$ & $\begin{array}{c}\text { Not permanent } \\
\text { Biogeoclimatic } \\
\text { zone and } \\
\text { landscape }\end{array}$ & $\begin{array}{c}\text { Not mentioned } \\
\text { Watershed and stand }\end{array}$ & $\begin{array}{l}\text { Permanent } \\
\text { Stand }\end{array}$ \\
\hline \multirow[t]{2}{*}{$\begin{array}{l}\text { Riparian } \\
\text { buffer }\end{array}$} & Temporal & $\begin{array}{l}\text { No detailed } \\
\text { strategy }\end{array}$ & Not all permanent & Not mentioned & Not all permanent & Permanent \\
\hline & Spatial & $\begin{array}{l}\text { No detailed } \\
\text { strategy }\end{array}$ & Stand & Stand & $\begin{array}{l}\text { Subregional and } \\
\text { watershed }\end{array}$ & Watershed \\
\hline \multirow[t]{2}{*}{ Corridor } & Temporal & $\begin{array}{l}\text { No detailed } \\
\text { strategy }\end{array}$ & Not mentioned & Not mentioned & Not permanent & No detailed strategy \\
\hline & Spatial & $\begin{array}{l}\text { No detailed } \\
\text { strategy }\end{array}$ & Ecodistrict & Landscape & $\begin{array}{c}\text { Subregional, } \\
\text { landscape, watershed }\end{array}$ & No detailed strategy \\
\hline \multirow[t]{2}{*}{$\begin{array}{l}\text { Large forest } \\
\text { patch }\end{array}$} & Temporal & $\begin{array}{l}\text { No detailed } \\
\text { strategy }\end{array}$ & Not permanent & Permanent & Not all permanent & Not all permanent \\
\hline & Spatial & $\begin{array}{l}\text { No detailed } \\
\text { strategy }\end{array}$ & Ecodistrict & Landscape & $\begin{array}{l}\text { Subregional, watershed } \\
\text { and landscape }\end{array}$ & Federal land \\
\hline Old forest & $\begin{array}{l}\text { Temporal } \\
\text { Spatial }\end{array}$ & $\begin{array}{l}\text { Not mentioned } \\
\text { Landscape }\end{array}$ & $\begin{array}{l}\text { Not mentioned } \\
\text { Landscape }\end{array}$ & $\begin{array}{l}\text { Not all permanent } \\
\text { Biogeoclimatic } \\
\text { zone and } \\
\text { landscape }\end{array}$ & $\begin{array}{l}\text { Not mentioned } \\
\text { Subregional }\end{array}$ & $\begin{array}{l}\text { Not mentioned } \\
\text { Watershed }\end{array}$ \\
\hline
\end{tabular}

No detailed strategy $=$ the element is mentioned but no strategy is explained.

Not mentioned $=$ a strategy is mentioned for the element, but there is no mention of the permanence of the retention element.

Not permanent $=$ the strategy permits an eventual removal of the element.

Not all permanent $=$ the strategy permits eventual removals of part of the element.

Ensuring recruitment $=$ green trees are maintained to ensure DWD and snag recruitment.

Permanent $=$ the element is maintained for multiple rotations

reference (e.g., past, present, future) for the forest of reference, the inclusion of global changes in forest of reference or not, and when information about the forest of reference was gathered (before or after creation of the guides). The two criteria used to analyze the text dealing with the seven retention elements were the following: the temporal scale (level of permanence: not permanent, not all permanent, thereby ensuring recruitment, and permanent) and the spatial scale (stand, landscape, watershed, region, territory) used in each retention element strategy.

From this analysis two tables were created for the second question. We created Table 2 to show at which spatial and temporal scale each guide chose to implement each retention element, given that a retention element can be implemented at more than one spatial or temporal scale. The strategies that were proposed for each retention element are summarized in Table 3 from the coded text created in the second step.

\section{Results}

Is END used as one of the conceptual bases to implement EM?

All guides, except for the oldest example of the North West Forest Plan (NWFP) ${ }^{3}$, clearly refer to END as one of their conceptual bases for implementing EM. In these guides, the term

${ }^{3}$ We do not cite the reference each time a guide is mentioned in the results and discussion section. Please see references to guides in Table 1. "natural disturbance" was always linked to "emulate", "mimic", "approximating", "resemble", and "simulate". This is exemplified by a statement from the Biodiversity Guidebook (BG): "The more the managed forests will look like the forests established after natural disturbances, the greater is the probability that all native species and ecological processes are maintained" (Province of British Columbia 1995). In the case of the NWFP, "natural disturbance" was instead linked to the concepts "maintaining disturbance regimes" and "management of disturbance risk". In this guide, it is only in late-successional reserves that the term "recreate" is linked to pre-settlement conditions.

For the four guides that endorsed END, identification of a dominant natural disturbance per territory is central to the choice of retention strategies that should be implemented. For example, in British Columbia, the amount of mature and overmature forest to be maintained in a landscape that is dominated by rare stand-initiating disturbances will be much higher than in landscapes that are dominated by frequent stand-initiating disturbances.

\section{Forest of reference}

In all guides, forests of reference refer to the pre-settlement period without any further specification, despite the fact that recommendations for retention elements mostly depend on the historic disturbance type. The strategy that is often used to 
Table 3: Summary of strategies used by each guide for each retention element.

\begin{tabular}{|c|c|}
\hline & Downed woody debris \\
\hline NDPE & Avoid full tree harvesting, leave non-merchantable logs on site and redistribute roadside chipping waste. \\
\hline GFE & $\begin{array}{l}\text { Maintain minimum } 50 \% \text { of pre-treatment coarse woody debris in the same diversity of size and species. Allow } 10 \text { to } 20 \\
\text { green trees } / \text { ha with a DBH } \geq 30 \mathrm{~cm} \text { to ensure snag and DWD recruitment and also leave tree limbs and tops. }\end{array}$ \\
\hline BG & Maintain minimum $50 \%$ of pre-treatment coarse woody debris. \\
\hline CIT & $\begin{array}{l}\text { Maintain biological legacy, including coarse woody debris. Where necessary restore biological legacies. No detailed } \\
\text { strategy. }\end{array}$ \\
\hline \multirow[t]{2}{*}{ NWFP } & $\begin{array}{l}\text { In the matrix, a prescription for each geographical region should be developed. Maintain bigger downed logs }(>40 \mathrm{~cm} \\
\text { diameter) between } 15 \mathrm{~m} \text { and } 30 \mathrm{~m} \text { of logs/ha. Downed woody debris must be appropriate in quantity, quality (such as } \\
\text { species, decay stage and size) and distribution. DWD already on the ground should be retained. DWD quantity and } \\
\text { quality must reflect rare and locally endemic species needs. }\end{array}$ \\
\hline & Snag \\
\hline NDPE & Maintain 25 individual trees or snags per hectare (ha) or create them mechanically. \\
\hline GFE & $\begin{array}{l}\text { Maintain } 8 \text { potential cavity trees/ha and } 8 \text { snags/ha. Allow } 10 \text { to } 20 \text { green trees/ha with a } \mathrm{DBH} \geq 30 \mathrm{~cm} \text { to ensure snag } \\
\text { and DWD recruitment }\end{array}$ \\
\hline BG & $\begin{array}{l}\text { Some existing snags should be retained, but equally important is ensuring that new snags will be recruited into the stand } \\
\text { in the future. Retain some live trees during harvesting as a source of large-diameter snags in the subsequent rotation. } \\
\text { Also create snags. }\end{array}$ \\
\hline CIT & Maintain biological legacy, including snags. Where necessary restore biological legacies. No detailed strategy. \\
\hline \multirow[t]{2}{*}{ NWFP } & $\begin{array}{l}\text { Maintain enough cavity trees to preserve } 40 \% \text { of the cavity-nesting bird population. Ensure future snag recruitment by } \\
\text { living large trees. }\end{array}$ \\
\hline & Green tree \\
\hline
\end{tabular}

NDPE Percent residual area must vary between $10 \%$ and $50 \%$, including a range of $2 \%$ to $10 \%$ for internal (inside the cutting area) and $8 \%$ to $40 \%$ for peninsular patches (at the margin of the cutting area). Harvesting allowed in $50 \%$ of retained patches when surrounding vegetation has reached $>3 \mathrm{~m}$ height. Maintain individual trees ( 25 trees/ha). No harvest and restricted harvest buffers exist for areas of concern, like nesting sites of bald eagles, great blue herons and ospreys.

GFE In clear cuts, maintain patches of minimum 1.0 ha in each 20 ha instead of individual trees. Tree islands should have tree species composition that is representative of the harvested stand.

BG The $\%$ of trees left depends on the \% landscape already harvested and on the \% allowed cuts in the biogeoclimatic sub-zone. Patches must be well-distributed in the cutting area and separated by a maximum of $500 \mathrm{~m}$. No harvesting is permitted in patches until the surrounding forest has reached a structural diversity equivalent to natural habitat for wildlife. A diversity of species must be maintained.

CIT Maintain 15 to $70 \%$ of retention on site, depending on watershed risk targets and site objectives. Distribute the retention (aggregated ( $>1 \mathrm{ha}$ ) or dispersed retention) to represent rare and at risk ecosystems.

NWFP In the matrix, retain at least $15 \%$ of the area in individual or patches of living trees. Patches ( $70 \%$ of green tree retention must be in patches of 0.2 ha to more than 1.0 ha and a minimum of patches $>1$ ha) should be retained indefinitely. Relative proportion of patches vs single trees retained must reflect local knowledge of individual species needs, especially rare and locally endemic species.

\section{Corridors}

NDPE No mention of corridors, but clear cuts must be separated by strips of $200 \mathrm{~m}$ to $600 \mathrm{~m}$ and more (peninsular patches, see green trees).

GFE Maintain corridors $200 \mathrm{~m}$ in width and maximum $3 \mathrm{~km}$ in length in ecodistricts characterized primarily by gap-driven disturbance. Corridors should reflect pre-settlement composition (stand type and age class) and structure (closedcanopy). Protected areas are connected by corridors

BG Not mentioned clearly, but seems to be part of Forest Ecosystem Network.

CIT Maintain connectivity for red- and blue-listed and focal wildlife species with the creation of reserve corridors, where no or very little extractive resource use takes place.

NWFP See the Connectivity/Diversity Block standards and guidelines, not in the NWFP. In NWFP riparian reserve $=$ corridors.

define the natural forests of reference and to implement END is the creation of a historical portrait. This historical portrait details the natural disturbance history and historical forest inventory data for the pre-industrial vegetation conditions. In fact, for the two most recent guides (Ecosystem-based management planning handbook [CIT] and Forest management guidelines to protect native biodiversity in the Greater Fundy Ecosystem [GFE]), the historical portrait of the whole territory was done before the actual creation of the guides. That method clearly influenced the way in which these guides were compiled. For 
Table 3: Summary of strategies used by each guide for each retention element. (continued)

\begin{tabular}{ll}
\hline & Riparian buffer \\
\hline NDPE & Riparian buffer mentioned but no clear strategy presented. \\
GFE & Maintain a riparian buffer of 30 to $60 \mathrm{~m}$ in which a partial cut can be applied, except within 5 m of the shoreline. \\
BG & Riparian buffers are part of the Forest Ecosystem Network (FEN). See the Riparian Management Area guidebook \\
CIT & $\begin{array}{l}\text { Maintain } 30 \text { to } 97 \% \text { of riparian buffer, depending on the risk level and spatial scale. Targets are developed at various } \\
\text { spatial scales. Targets at lower scale depend on average targets at higher scale. }\end{array}$ \\
NWFP & $\begin{array}{l}\text { Maintain riparian reserve. Width of riparian reserve is established based on ecological and geomorphic factors during } \\
\text { the watershed analysis. The percent of area in riparian reserves varies among administrative units. No harvesting, } \\
\text { grazing, mining or recreational activities are permitted in riparian reserves (buffer). }\end{array}$
\end{tabular}

\section{Large forest patch different than protected areas}

NDPE No clear strategy presented to leave patches greater than 1 ha. Protected areas are only large patches and are defined in Ontario's Living Legacy.

GFE Keep habitats of different sizes with at least one of 1000 ha by cover type in ecodistrict characterized by gap-replacing disturbance. In ecodistricts characterized by stand-replacing disturbance, maintain patches of 375-500 ha. Also, maintain ecologically significant areas and apply a variable-width buffer. Harvesting can be allowed. These strategies complement protected areas.

BG Maintain patches in a variety of sizes. Size and number depend on the biodiversity emphasis and the natural disturbance type. Larger ones are called reserves and they may be areas requiring special management or even total protection from harvesting, to complement protected areas (see the provincial biodiversity strategy).

CIT Make reserves, where no, or very little, extractive resource use takes place, to complement protected areas (see $B C$ Protected Areas Strategy) for rare ecological features, red- and blue-listed communities and focal species. Analyze wildlife requirements at each spatial scale.

NWFP Maintain Managed Late-Successional Areas, Late-Successional Reserves, Administrative Withdrawals, Riparian Reserves and Congressionally Reserved areas for a total of $72 \%$ of federal lands. Buffers around spotted owl (100 acres), marbled murrelet and late-successional forest associated species habitats are also needed if they are in the matrix. Protected areas are included in these designations.

\section{Old forest}

NDPE Vary treatment to keep a proportion of uneven-aged forest and an age-class structure similar to pre-industrial landscape see the "Old Growth Policy for Ontario's Crown Forest" (OMNR 2003)

GFE In ecodistricts dominated by gap-replacing disturbance, maintain 40 to $85 \%$ of the forest landscape in mature or overmature forest and 10-12\% of this landscape should have old-growth characteristics. In ecodistricts that are dominated by stand-replacing disturbance, maintain 35 to $40 \%$ of the forest landscape in mature or over-mature forest.

BG Determine the approximate natural seral stage distribution, based on estimates of the long-term average interval between stand-destroying events for each landscape by biogeoclimatic zones. Maintain from 50 to $70 \%$ of natural seral distribution in each ecosystem type. This means that, depending on the natural disturbance type, from 8 to $54 \%$ of the forest landscape must be mature or over-mature forest. When those objectives of representation and old forests are not met with FEN, it is suggested that an Old growth management area be created to fill the gap. Old growth management areas can be harvested when equivalent old-seral stage areas are available.

CIT Maintain 50 to $70 \%$ of the natural old-seral distribution in each ecosystem type, depending on the risk level and spatial scale. Targets are developed at various spatial scales. Targets at lower scales depend on average targets at higher scales. Where necessary estimate old forest restoration requirements. Prevent excessive mid-seral representation.

NWFP In the matrix, maintain at least 15\% of the watershed in old-growth stage. Late-Successional Reserves and Managed LateSuccessional Areas (prohibit or limit activities) are used to recreate and maintain pre-settlement distributions of age class and composition.

The wording from the guides is retained when possible.

the NDPE, the historical portrait is done whenever a new unit is planned and so the overall guidelines tend to be more general to accommodate various types of disturbances. For $\mathrm{BG}$, the natural disturbance type is already determined in the guide for each existing biogeoclimatic zone in British Columbia. New information about the forest of reference is needed only to plan connectivity. Indeed, it is recommended that a connected landscape should be maintained in the same manner as in pre-industrial times. None of the guides discussed the possible changes in forest dynamics due to global change (e.g., modification of disturbance regimes, deer browsing). Only the NDPE briefly recommends combining long-term simulations with pre-settlement information.

Since legacy elements are important for ecological processes and biodiversity, are the temporal and spatial scales proposed for retention elements appropriate to achieve EM objectives? Following the evaluation of the five guides, we noted that several important points concerning the spatial and temporal scales that had been proposed were not totally congruent with what 
is found in the scientific literature (Fig. 1). These included the temporal maintenance of retention, the ecological justification of the spatial scale that was used, and the integration of multiple spatial scales.

Before presenting our evaluation of each guide, we need to specify that the different strategies present in Table 3 are dependent on a certain land classification. For example, in GFE and BG, the land is subdivided according to the dominant disturbance type ${ }^{4}$. The land can also be subdivided according to the risk level ${ }^{5}$ (CIT), the biodiversity emphasis ${ }^{6}$ (BG), or an ecological land classification ${ }^{7}$ (GFE). Depending on the land classification, the strategy for a given retention element will be different. For example, in lands chosen for high biodiversity emphasis, large patches will be bigger and more abundant (BG). For its part, the NWFP conducted a watershed analysis ${ }^{8}$ during management planning. This analysis also modulates some retention element strategies.

\section{Temporal maintenance of retention}

Despite certain exceptions, the guides are generally ambiguous with respect to the long-term maintenance of retention elements. Globally, only protected areas and recruitment of DWD and snags have clear long-term strategies that are common to all guides. Only the CIT guide had no clear strategies for woody debris. For many retention elements no mention is made of the period of time that the elements should be maintained. When duration is mentioned, it is often to state when the elements can be partially or totally removed before the next rotation (Tables 2 and 3). For example, it is possible in the NDPE to cut retention patches when the surrounding forest reaches a height of $3 \mathrm{~m}$. In the $\mathrm{BG}$, it is proposed that structural diversity ${ }^{9}$ equivalent to that found in natural forests must be recreated in the surrounding forest before a final cut in the retention area can be allowed (Table 3). This also means that retention is not permanent, although it could be maintained for a certain length of time. The same observation can

${ }^{4}$ Dominant disturbance type: GFE = Gap-replacing disturbance, Patchreplacing disturbance and Stand-replacing disturbance. $\mathrm{BG}=$ Rare stand-initiating, infrequent stand-initiating, frequent stand-initiating, frequent stand-maintaining, alpine tundra, and sub-alpine. One disturbance type is given per biogeoclimatic zone.

${ }^{5}$ Risk level: There are four possible designations, from very low to high. Low $=$ meaning a $30 \%$ difference from what is found naturally. High $=$ meaning a $70 \%$ difference from what is found naturally.

${ }^{6}$ Biodiversity emphasis: There are three designations that may have a landscape unit in connection with the risk to biodiversity loss: Low = Priority given to social and economic objectives $(30 \%-55 \%$ of the region and not all in the same area). Intermediate $=$ Trade-off between conservation and timber production $(35 \%-60 \%$ of the region). High $=$ Higher priority to conservation ( $10 \%$ of the region).

${ }^{7}$ Ecological Land Classification is a hierarchical classification of ecological units at multiple scales.

${ }^{8}$ Watershed analysis: Procedures for conducting an analysis that evaluates geomorphic and ecologic processes operating in specific watersheds. Prior to resource management, it delineated riparian reserves. ${ }^{9}$ Structural diversity: "A variety of canopy layers (vertical structure) and spatial patchiness (horizontal structure). This variety of layers includes the naturally occurring forest understory of shrubs and forbs, which provide food and cover for numerous species. To maintain understory vegetation, a partially open or patchy forest canopy is required" (Province of British Columbia 1995). be applied to riparian buffers; in some circumstances, partial cuts are allowed within these areas, e.g., in the GFE and CIT guides (Table 3). Even old forests are not clearly identified as permanent features (Table 2). Only the two west coast guides (BG and NWFP) recommend maintaining retention features for more than one rotation. The BG recommends a longterm landscape management approach in creating the Forest Ecosystem Network (see definition in the following section: Spatial multi-scale approach), in which some components should be permanent reserves. The NWFP guide mentioned that $15 \%$ of the stand must be maintained as permanent green tree retention (over multiple rotations) and that no subsequent cuts are allowed in riparian buffers (Table 3).

\section{Determination of spatial scale based on ecological considerations}

All guides subdivide their respective territories into a minimum of three spatial scales: from the stand to the region or greater (Table 2). The spatial scales were rarely defined by guides. We assumed that they are quite similar in each guide, but it remains a possible source of bias in the comparison. In general, recommendations are made explicit for the stand and landscape scales, but the proposed standards are not necessarily based on ecological knowledge. Rather, they are the result of practical decisions (e.g., management unit dimensions and respect of administrative borders). Large patches, old forest and corridors are mainly considered at the landscape scale, while DWD, snags and riparian reserves are planned at the stand scale (Table 2). Some guides made exceptions and have proposed targets at broader scales, such as the ecodistrict (GFE) or biogeoclimatic zone (BG). These scales are more ecologically significant because it is at these scales that the natural disturbance type is delineated. For example, in the GFE, corridors and large patches are planned at the ecodistrict scale. Similarly in the BG, green tree retention and old seral class distributions are determined by biogeoclimatic zone. The NWFP and CIT guides are innovative in recommending watershed-scale planning for many retention elements, such as old-growth forest and riparian buffers. Indeed, in the NWFP, $15 \%$ of the watershed should be in the old-growth stage (Tables 2 and 3 ).

\section{Spatial multi-scale approach}

As previously stated, most recommendations are made for stand and landscape scales, but also were frequently implemented at only one of these scales. The lack of integration between scales can lead to concerns about connectivity. For example, in the NDPE guide, connectivity is represented solely by the remaining riparian reserves and peninsular patches at the stand scale and no analyses that would ensure connectivity are conducted at larger scales (Table 2). Only two guides make a notable effort to integrate spatial scales. The BG integrates biogeoclimatic and landscape scales in its requirements for the creation of a "Forest Ecosystem Network" in which the links among all components are viewed as essential. It includes a variety of protected areas, inaccessible forests, riparian buffers, high visual quality areas, wetlands, old forests, and corridors. In FEN, the degree of connectivity depends on the biodiversity emphasis (importance put on biodiversity) and the dominant disturbance type (Table 3). In the CIT guide, an example of integration across scales is that corridors and large patches are planned at the subregional-, landscape- and watershed-scales. For these two guides, 
strategies that are implemented at smaller scales depend on strategies developed at coarser scales (Tables 2 and 3).

\section{Discussion}

Is END used as one of the conceptual bases to implement $E M$, and if so, what strategies are used to define the natural forest of reference?

END is an important theoretical component in each of the approaches that were listed for implementing EM, except in the region in which EM was first implemented (USDA and USDI 1994). The NWFP is the oldest guide and was created only one year after Hunter's (1993) proposal for END, which may explain why END is not explicitly described in this guide. The creation of a guide is a long and laborious process that often starts many years before publication. Despite END being central to most of the guides, the temporal reference period for which the natural disturbance regime is to be emulated has not been clearly stated in any of them. Yet, general references are mentioned that provide some idea as to the targeted time period, such as pre-industrial, pre-European, and pre-settlement periods. This being said, several researchers have shown evidence that disturbance regimes are constantly changing (Bergeron and Flannigan 1995, Logan et al. 2003, Bergeron et al. 2006) and that this temporal variability should be considered when the emulation of a certain pre-settlement period is planned. Landres et al. (1999) proposed that no a priori time period or spatial extent should be used in defining the natural range of variability. According to these authors, specific goals, site-specific field data, inferences that were derived from data collected elsewhere, simulation models, and explicitly stated value judgements must all contribute to the selection of the relevant time period and the spatial extent that is used in defining natural variability. Only one guide (NDPE), however, partially integrates simulations into its strategy to define forest conditions by combining long-term simulations with pre-settlement information.

The determination of a historical portrait each time that a new management unit is planned, as some guides suggest, is necessary to maintain the natural variability that occurs among units within the same region. Past conditions are a good starting point for understanding the processes and functions that are associated with forest resilience to natural conditions. However, this strategy does not consider that current and future conditions under which forests will develop are likely to be different from those of the past. Many global conditions are changing. Climate, atmospheric concentrations of $\mathrm{CO}_{2}$, acid precipitation, nitrogen deposition levels, and invasive species and pests, together with permanent fragmentation of the landscape (Ruckstuhl et al. 2008, Thompson et al. 2009), are all factors that should be considered in our planning. These considerations could be at least partially considered through long-term modelling of future conditions and monitoring of the forest of reference. This is a compromise between what Landres et al. (1999) have suggested and the analysis of the pre-settlement forest alone. We believe that EM should still use information on pre-settlement natural variability, but this information must also be evaluated in light of changing global environmental, social and economic conditions to create a forest that will be as resilient as possible to unknown future conditions (Puettmann et al. 2009, 2011). Basing the management of our future forests on conserving the complexity of systems could help achieve the long-term objective of preserving the multitude of ecosystem services that forests provide (Puettmann et al. 2009, Witté 2012).
Since legacy elements are important for ecological processes and biodiversity, are the temporal and spatial scales proposed for retention elements appropriate to achieve EM objectives? Temporal scale

The greatest weakness that was identified in all guides was the lack of temporal consideration for most of the retention elements that were being proposed. In contrast to spatial scales, temporal scales are nearly absent from any discussion in the guides that we surveyed. It is obvious that some elements, other than protected areas, need to be maintained over many rotations to better emulate natural disturbances and to fulfill ecological roles (Drapeau and Imbeau 2006). In this sense, it is a positive step that some guides have planned for the recruitment of snags and DWD in the next rotation, because the maintenance of these key forest attributes is essential for many species (Deans et al. 2003, Crête et al. 2004, Drapeau and Imbeau 2006). A minimum degree of permanent retention is needed, even if the amount and the duration of these elements vary considerably with the dominant disturbance regime. All natural disturbances generate retention elements at diverse spatial scales that are maintained for much longer than the conventional harvest rotation, which tends to vary from 60 to 100 years or longer (Hopwood 1991, McRae et al. 2001, Perron et al. 2008). Without some specifications regarding the temporal scale over which retention elements are to be retained, there is a great risk that many crucial structural elements will not be maintained for a period of time sufficient to fulfill their ecological functions. For example, if riparian buffers and corridors are not maintained over multiple rotations, some species that require old forests, such as woodland caribou (Rangifer tarandus caribou), could be affected, (Courtois et al. 2004).

The lack of clear long-term temporal considerations regarding retention elements in all guides is clearly symptomatic of the static viewpoint of western society regarding natural ecosystems. The uncertainty and complexity of managing for the long-term clearly exceeds the capacity (financial and technical) of most stakeholders to address these issues (Brunner and Clark 1997). Yet, the lack of knowledge regarding the long-term dynamics and ecological effects of the retention elements that are retained (Rosenvald and Lohmus 2008) is probably the main explanation for the lack of a temporal consideration in many of the guides. To develop adequate recommendations, more long-term research is needed with respect to the temporal role of a given retention element for the maintenance of ecological processes and biodiversity. More research on monitoring, modelling and analyses of ecosystem functions is needed (Handcock and Csillag 2004, Rosenvald and Lohmus 2008), especially in the context of global change (Heller and Zavaleta 2009). Adaptive management through monitoring and readjustment of management approaches will be critical in ensuring the longterm success of EM approaches that are being attempted in all of these regions. Fortunately, most guides have monitoring plans.

Forest ecosystem values (economic and social, among others) are also diverse (Tarrant et al. 2003, Nadeau et al. 2007, Roy 2008), which increases the complexity of managing all retention elements through time and space without being in conflict with multiple human activities in forested landscapes (DeFries et al. 2007). In that sense, all guides made an effort to involve a wide variety of stakeholders in their creation. In turn, many targets (e.g., percentage of old forest and size of patches) appear to be more the result of a consensus among stakeholders than based on strong scientific knowledge. For example, there 
is no justification for maintaining $15 \%$ of the watershed in the old-growth stage considering that, in the United States, "the historical extent of old-growth forest in the Pacific Northwest was roughly two-thirds of the total land area" (Strittholt et al. 2006). Lower levels could be justified if some threshold values for the maintenance of biodiversity or ecological function had been determined previously, but such information is often lacking and difficult to obtain. There is no doubt that involvement of various stakeholders is an important step forward in the democratization of forest management, but basic scientific information regarding ecological thresholds is also needed to reach EM objectives. We suggest applying the precautionary principle by emphasizing the importance of planning more permanent retention, such as large patches, corridors, and riparian buffers where no future harvest is permitted. This recommendation is even more important in areas that are dominated by infrequent natural disturbances. We also must highlight the fact that it can be challenging to have a democratic decision-making process and at the same time make sound scientific decisions (Holmgren 2012).

\section{Spatial scale}

Proposals that address management at various spatial scales are a significant advancement over past practices, which focused on the stand scale. However, the ecological significance of scales needs to be clearly addressed. For example, the use of the watershed to create management units, as implemented in the two western guides (CIT guide and NWFP), is better linked to natural processes. It is at the watershed level that hydrological and geomorphological processes occur, such as the generation of sediment loads, erosion, and flooding (Hopwood 1991). For other guides, in contrast, the determination of stand and landscape scales is based on traditional management scales, which may have little ecological relevance. Indeed, the determination of scales is often not focused on when meeting ecological objectives, but it is based instead on logistical considerations. To follow the precepts of END, the management scale must be congruent with the dimensions of the natural disturbances being emulated (Perera et al. 2004). Following this logic, the largest scale (region) that is used in the boreal forest should be large enough to cover the largest fire events, whereas in forest landscapes dominated by small-scale perturbations, such as coastal forests (Gavin et al. 2003, Pearson 2010), much smaller units could be used. Using appropriate scales that are based on ecological justifications (Christensen et al. 1996) will help us to establish retention targets that are appropriate to the prevalent natural disturbances of the region. In that sense, the BG uses biogeoclimatic zones and the GFE, the ecodistrict zone, to determine the dominant natural disturbance. Subsequently, recommendations regarding retention elements should be modulated depending on the dominant disturbance in the biogeoclimatic or ecodistrict zone being evaluated.

Another weakness of the guides is that most of the targets are developed at only one spatial scale. Targeting various scales, as was proposed in the CIT and BG guides, is more likely to recreate the natural range of variability (Landres et al. 1999). Indeed, all retention elements must be analyzed and planned at different scales to adequately represent all possible ranges of variability that are found in the landscape being managed (Lindenmayer 2000). The lack of multi-scale approaches can lead to several problems concerning proposed strategies for these retention elements. Many phenomena such as connectivity are visible at different scales. Moreover, the interdependence of scales makes understanding of a phenomenon at one scale difficult (Levin 1992).

For forest biota, connectivity is of the utmost importance in maintaining biodiversity across the territory (Bennett 2003) and, thus, should not be managed at only one spatial scale. Management exclusively at the stand scale is not particularly useful, as scaling up can lead to homogenization at larger scales. The use of a riparian buffer that ensures connectivity within a territory is a good first step, but this approach needs to be complemented by strategies at larger scales. Furthermore, it cannot always be assumed that riparian reserves that are managed at the stand scale will be sufficiently numerous and dispersed across the landscape to fully link retention elements. Three guides have suggested, in addition to riparian reserves, the use of corridors to ensure landscape connectivity. Probably the most highly developed proposition concerning connectivity is the Forest Ecosystem Network that is described in the BG guide. It is the only strategy that places emphasis on connectivity among all retention elements at both the scale of the landscape and that of the biogeoclimatic zone.

\section{Recommendations}

Following the comparison of the five guides, we have made a number of proposals (Table 4). First, a better effort should be made to clearly define the forest of reference. Also, consideration of the effects of global change should be included in this determination. Second, the temporal and spatial scales that are used to develop strategies for retention elements should be made more explicit. More generally, there was variation in the guides in their coverage of END, and in temporal and spatial scales of retention. Some guides have more complete strategies than others concerning these issues (Table 3). Finally, we highlight (Table 4) the strategies that have been already proposed in some guides, and that address many of our concerns. In doing so, we hope to facilitate their use in future versions of guides or in guides that are currently being developed in other jurisdictions.

\section{Conclusion}

The implementation of EM strategies and guidelines in North America, as we have compared here among the five guides, is an important first step towards a more holistic approach to management. We are now far from past management strategies at the stand scale that dealt only with the production of timber. This review has highlighted many weaknesses where further improvements are required for the implementation of EM:

- The pre-settlement forest is usually chosen as the forest of reference, but the use of the pre-settlement forest does not take into account possible alterations in forest ecosystems due to global change. To address this problem, we suggest integrating notions of resilience and complexity with the historical portrait, together with modelling potential future conditions, for the creation of new guidelines. In doing so, we think that the forest will be more adaptable to the most likely outcomes of global change (Messier et al. 2013). 
Table 4: Principal weaknesses identified in five EM guides from North America, together with proposals and existing strategies for addressing them

Weaknesses

Lack of details on the natural disturbance regime to recreate/emulate.

Lack of emphasis on the temporal maintenance of retention

The determination of spatial scale is not always based on ecological considerations

The analysis of each retention element is conducted at only one spatial scale

Proposals

Existing strategies (see Tables 2 and 3 for more detail)

An integration of pre-settlement, actual and future information (modelling) about the forest dynamic should be analyzed with the objective of basing our strategies on a more realistic forest of reference.

The analysis of the forest of reference must be performed at various spatial and temporal scales. Global changes should be part of the modelling exercise.

Better planning for retention in time. Some components, other than protected area, need to stay longer than the first pass. The duration and choice of retention elements should be based on ecological considerations, (e.g., the needs of wildlife) and be based on the dominant natural disturbance. Rotation length should be inspired by natural disturbances when possible.

The determination of spatial scales should be based on ecological processes, like natural disturbance. For example, use of an ecological classification, the watershed, and the disturbance type to define the scales should be encouraged.

Set targets for each retention element at various spatial scales in order to help recreate the natural range of variability and avoid connectivity problems.
Only NDPE briefly discusses modelling.
NDPE, GFE and NWFP proposed to ensure the recruitment of CWD and snags over multiple rotations. NWFP suggests avoiding management in green tree patches and riparian buffer. BG suggests creating reserves to complement protected areas.

GFE used the ecodistrict, BG the biogeoclimatic zone and the watershed is used by CIT and NWFP. These scales are more ecologically appropriate.

The BG and CIT proposed well integrated multi-scale approaches, including the Forest Ecosystem Network strategy by BG.
- The lack of consideration of the temporal scale of retention is probably the single greatest weakness that is shared by most guides. It is essential to plan for much longer periods of time to ensure that retention elements fulfil their diverse ecological roles. This means that some retention elements need to be maintained over many rotations.

- No multi-scale approach that was proposed by any guide is sufficiently complete. A multi-scale management approach is critical in EM to maintain biodiversity and ecological processes within a given territory. Some good strategies are presented at different spatial scales, but improvements can still be made. For example, the scales chosen should be justified ecologically (e.g., use of watersheds) and targets for each retention element should be presented at various spatial scales (to avoid connectivity problems).

This review has focused on the ecological issues of EM, particularly retention elements, without addressing other concerns such as social or economic aspects. Clearly, these issues also affect the way in which EM is implemented and, thus, the role of socio-economic concerns should be treated in future evaluations.

\section{References}

Andren, H. 1994. Effects of habitat fragmentation on birds and mammals in landscapes with different proportions of suitable habitat: a review. Oikos 71: 355-366.

Archibald, D.J., W.B. Wiltshire, D.M. Morris and B.D. Batchelor. 1997. Forest management guidelines for the protection of the physical environment, version 1.0. Ontario Ministry of Natural Resources, Toronto, ON. 42 p.

Armstrong, G.W., W.L. Adamowicz, J.A. Beck, S.G. Cumming and F.K.A. Schmiegelow. 2003. Coarse filter ecosystem management in a nonequilibrating forest. Forest Science 49(2): 209-223.
Bengston, D.N. 1994. Changing forest values and ecosystem management. Society and Natural Resources 7: 515-533.

Bennett, A.F. 2003. Linkages in the landscape the role of corridors and connectivity in wildlife conservation. IUCN, Gland, Switzerland and Cambridge, UK. xiv + 254 p.

Bergeron, Y. et al. 2006. Past, current, and future fire frequencies in Quebec's commercial forests: implications for the cumulative effects of harvesting and fire on age-class structure and natural disturbancebased management. Canadian Journal of Forest Research 36(11): 2737-2744.

Bergeron, Y. and M.D. Flannigan. 1995. Predicting the effects of climate change on fire frequency in the southeastern Canadian boreal forest. Water, Air, \& Soil Pollution 82(1): 437-444.

Bergeron, Y., A. Leduc, B.D. Harvey and S. Gauthier. 2002. Natural fire regime: A guide for sustainable management of the Canadian boreal forest. Silva Fennica 36(1): 81-95.

Berry, J., G.D. Brewer, J.C. Gordon and D.R. Patton. 1998. Closing the gap between ecosystem management and ecosystem research. Policy Sciences 31(1): 55-80.

Betts, M. and G. Forbes. 2005. Forest Management Guidelines to Protect Native Biodiversity in the Greater Fundy Ecosystem. 2nd ed. New Brunswick Co-operative Fish and Wildlife Research Unit, University of New Brunswick, Fredericton, NB. 110 p.

Brunner, R.D. and T.W. Clark. 1997. A practice-based approach to ecosystem management. Conservation Biology 11(1): 48-58.

Butler, K.F. and T.M. Koontz. 2005. Theory into practice: Implementing ecosystem management objectives in the USDA Forest Service. Environmental Management 35(2): 138-150.

Christensen, N.L. et al. 1996. The report of the Ecological Society of America committee on the scientific basis for ecosystem management. Ecological Applications 6(3): 665-691.

Cissel, J.H., F.J. Swanson and P.J. Weisberg. 1999. Landscape management using historical fire regimes: Blue River, Oregon. Ecological Applications 9(4): 1217-1231. 
Coast Information Team. 2004. Ecosystem-based management planning handbook. Coast Information Team. 88 p.

Courtois, R., J.P. Ouellet, C. Dussault and A. Gingras. 2004. Forest management guidelines for forest-dwelling caribou in Quebec. The Forestry Chronicle 80(5): 598-607.

Crête, M. et al. 2004. Pourquoi et comment maintenir du bois mort dans les forêts aménagées du Québec. Avis scientifique. . Société de la faune et des parcs du Québec: Direction du développement de la faune et Ministère des Ressources naturelles du Québec: Direction de l'environnement forestier, $35 \mathrm{p}$.

Crites, S. and M.R.T. Dale. 1998. Diversity and abundance of bryophytes, lichens, and fungi in relation to woody substrate and successional stage in aspen mixedwood boreal forests. Canadian Journal of Botany 76(4): 641-651.

Cyr, D., S. Gauthier, Y. Bergeron and C. Carcaillet. 2009. Forest management is driving the eastern North American boreal forest outside its natural range of variability. Frontiers in Ecology and the Environment 7(10): 519-524.

Dale, V.H., A.E. Lugo, J.A. MacMahon and S.T.A. Pickett. 1998. Ecosystem management in the context of large, infrequent disturbances. Ecosystems 1(6): 546-557.

Darveau, M. and A. Desrochers. 2001. Le bois mort et la faune vertébrée: état des connaissances au Québec. Ministère des Ressources Naturelles. Gouvernement du Québec, Québec.

Deans, A.M., J.R. Malcolm, S.M. Smith and T.J. Carleton. 2003. A comparison of forest structure among old-growth, variable retention harvested, and clearcut peatland black spruce (Picea mariana) forests in boreal northeastern Ontario. The Forestry Chronicle 79(3): 579-589. DeFries, R., A. Hansen, B.L. Turner, R. Reid and J.G. Liu. 2007. Land use change around protected areas: Management to balance human needs and ecological function. Ecological Applications 17(4): 1031-1038.

Drapeau, P. and L. Imbeau. 2006. Conséquences et risques potentiels inhérents à la récolte des forêts résiduelles laissées depuis 1988 au sein de grands parterres de coupe pour la faune associée aux forêts matures. Avis scientifique, Ministère des Ressources Naturelles et de la Faune, Direction de l’aménagement de la faune, Bureau régional Abitibi-Témiscamingue. $35 \mathrm{p}$.

Etheridge, D.A., D.A. MacLean, R.G. Wagner and J.S. Wilson. 2006. Effects of intensive forest management on stand and landscape characteristics in northern New Brunswick, Canada (1945-2027). Landscape Ecology 21(4): 509-524.

Franklin, J.F. 1993. Preserving biodiversity - Species, ecosystems or landscapes. Ecological Applications 3(2): 202-205.

Gauthier, S., M.-A. Vaillancourt, A. Leduc, L.D. Grandpré, D. Kneeshaw, H. Morin, P. Drapeau and Y. Bergeron. 2008. Aménagement écosystémique en forêt boréale: pour une foresterie qui séduque de la dynamique naturelle. Presse de l'Université du Québec, Québec. 672 p. Gavin, D.G., L.B. Brubaker and K.P. Lertzman. 2003. Holocene fire history of a coastal temperate rain forest based on soil charcoal radiocarbon dates. Ecology 84(1): 186-201.

Grumbine, R.E. 1994. What is ecosystem management? Conservation Biology 8(1): 27-38.

Gunderson, L.H. 2000. Ecological resilience in theory and application. Annual Review of Ecology and Systematics 31(1): 425.

Handcock, R.N. and F. Csillag. 2004. Spatio-temporal analysis using a multiscale hierarchical ecoregionalization. Photogrammetric Engineering and Remote Sensing 70(1): 101-110.

Hanski, I. 2000. Extinction debt and species credit in boreal forests: modelling the consequences of different approaches to biodiversity conservation. Annales Zoologici Fennici 37: 271-280.

Heller, N.E. and E.S. Zavaleta. 2009. Biodiversity management in the face of climate change: A review of 22 years of recommendations. Biological Conservation 142(1): 14-32.
Hessburg, P.F., J.K. Agee and J.F. Franklin. 2005. Dry forests and wildland fires of the inland Northwest USA: Contrasting the landscape ecology of the pre-settlement and modem eras. Forest Ecology and Management 211(1-2): 117-139.

Holling, C.S. 1973. Resilience and stability of ecological systems. Annual Review of Ecology and Systematics 4: 1-23.

Holmgren, P. 2012. Communication challenges in science for forest policy [online]. Center for International Forestry Research. Available from http://www.cifor.org/online-library/polex-ciforsblog-for-and-by-forest-policy-experts/english/detail/article/1222/ communication-challenges-in-science-for-forest-policy.html[Accessed26/ 10/2012.

Hopwood, D. 1991. Principles and practices of new forestry, 71. BC. Ministry of Forests, Victoria BC., 95 p.

Hunter, M.L. 1993. Natural fire regimes as spatial models for managing boreal forests. Biological Conservation 65(2): 115-120.

Jonsson, B.G., N. Kruys and T. Ranius. 2005. Ecology of species living on dead wood - Lessons for dead wood management. Silva Fennica 39(2): 289-309.

Kimmins, J.P. 2004. Emulating natural forest landscape disturbances: What does this mean? In A.H. Perera, L.J. Buse and M.G. Weber. Emulating Natural Forest Landscape Disturbances: Concepts and Applications. pp. 8-28. Columbia University Press, New York, NY.

Klenk, N.L., G.Q. Bull and J.I. MacLellan. 2009. The "emulation of natural disturbance" (END) management approach in Canadian forestry: A critical evaluation. The Forestry Chronicle 85(3): 440-445.

Landres, P.B., P. Morgan and F.J. Swanson. 1999. Overview of the use of natural variability concepts in managing ecological systems. Ecological Applications 9(4): 1179-1188.

Levin, S.A. 1992. The problem of pattern and scale in ecology. Ecology 73: 1943-1967.

Lindenmayer, D.B. 2000. Factors at multiple scales affecting distribution patterns and their implications for animal conservation - Leadbeater's Possum as a case study. Biodiversity and Conservation 9(1): 15-35.

Lindenmayer, D.B. and J.F. Franklin. 2002. Conserving forest biodiversity: A comprehensive multiscaled approach. Island Press, Washington, DC. $351 \mathrm{p}$.

Lindenmayer, D.B., J.F. Franklin and J. Fischer. 2006. General management principles and a checklist of strategies to guide forest biodiversity conservation. Biological Conservation 131(3): 433-445.

Lindenmayer, D.B. et al. 2012. A major shift to the retention approach for forestry can help resolve some global forest sustainability issues. Conservation Letters 5: 1-12.

Logan, J.A., J. Regniere and J.A. Powell. 2003. Assessing the impacts of global warming on forest pest dynamics. Frontiers in Ecology and the Environment 1(3): 130-137.

McRae, D.J., L.C. Duchesne, B. Freedman, T.J. Lynham and S. Woodley. 2001. Comparisons between wildfire and forest harvesting and their implications in forest management. Environmental Reviews 9(4): 223-260.

Messier, C., K.J. Puettmann and D.K. Coates. 2013. Managing Forests as Complex Adaptive Systems - Building Resilience to the Challenge of Global Change. Routledge, New York. 368 p.

Nadeau, S., T.M. Beckley, E.H. Kennedy, B.L. McFarlane and S. Wyatt. 2007. Opinions du public sur la gestion des forêts au NouveauBrunswick : rapport de lenquête provinciale. Ressources naturelles Canada - Service canadien des forêts - Centre de foresterie de l'Atlantique, Fredericton, NB. 76 p.

Noss, R.F. 1999. Assessing and monitoring forest biodiversity: A suggested framework and indicators. Forest Ecology and Management 115(2-3): 135-146.

[OMNR] Ontario Ministry of Natural Resources. 2001. Forest management guide for natural disturbance pattern emulation, Version 3.1. Ontario Ministry of Natural Resources, Toronto, ON. 40 p. 2003. Old Growth Policy for Ontario's Crown Forests. F.P.S.F.M. Branch, Sault-Ste. Marie, ON. 26 p. 
Pearson, A.F. 2010. Natural and logging disturbances in the temperate rain forests of the Central Coast, British Columbia. Canadian Journal of Forest Research 40(10): 1970-1984.

Perera, A.H., L.J. Buse and M.G. Weber. 2004. Emulating natural forest landscape disturbances: Concepts and applications. Columbia University Press, New York. xix +315 p.

Perron, N., L. Bélanger and M. Vaillancourt. 2008. Organisation spatiale des peuplements et de la forêt résiduelle sous régimes de feu et de coupes. In S. Gauthier et al. Vaillancourt Aménagement écosystémique en forêt boréale. pp. 157-163. Presse de l'Université du Québec, Québec.

Province of British Columbia. 1995. Biodiversity guidebook: Forest practices code of British Columbia. British Columbia Ministry of Forests and British Columbia Environment, Victoria, B.C. ix + 99 p.

Puettmann, K.J. 2011. Silvicultural challenges and options in the context of global change: "simple" fixes and opportunities for new management approaches. Journal of Forestry 109(6): 321-331.

Puettmann, K.J., K.D. Coates and C. Messier. 2009. A critique of silviculture: Managing for complexity. Island Press, Washington, DC. 200 p.

Rauscher, H.M., F.T. Lloyd, D.L. Loftis and M.J. Twery. 2000. Practical decision-analysis process for forest ecosystem management. Computers and Electronics in Agriculture 27: 195-226.

Rosenvald, R. and A. Lohmus. 2008. For what, when, and where is green-tree retention better than clear-cutting? A review of the biodiversity aspects. Forest Ecology and Management 255: 1-15.

Roy, M.-É. 2008. Résultats de l'enquête téléphonique sur les valeurs forestières des résidants des régions de la Capitale-Nationale et du Saguenay-Lac-Saint-Jean. Ministère des Ressources naturelles et de la Faune, Québec. 55 p.

Ruckstuhl, K.E., E.A. Johnson and K. Miyanishi. 2008. Introduction. The boreal forest and global change. Philosophical Transactions of the Royal Society B 363: 2245-2249.

Strittholt, J.R., D.A. DellaSala and H. Jiang. 2006. Status of mature and old-growth forests in the Pacific Northwest. Conservation Biology 20(2):363-374.
Tarrant, M.A., H.K. Cordell and G.T. Green. 2003. PVF: A scale to measure public values of forests. Journal of Forestry 101(6): 24-30.

Thompson, I., B. Mackey, S. McNulty and A. Mosseler. 2009. Forest Resilience, Biodiversity and Climate Change: A synthesis of the biodiversity/ resilience/ stability relationship in forest ecosystems, Technical Series no 43, Montreal, QC. 67 p.

USDA and USDI. 1994. Standards and guidelines for management of habitat for late-successional and old-growth forest related species within the range of the northern spotted owl. USDA (Forest Service) and the USDI (Bureau of Land Management). $152 \mathrm{p}$.

Vanha-Majamaa, I. and J. Jalonen. 2001. Green tree retention in Fennoscandian forestry. Scandinavian Journal of Forest Research 16 (Suppl. 3): 79-90.

Wallin, D.O., F.J. Swason, B. Marks, J.H. Cissel and J. Kertis. 1996. Comparison of managed and pre-settlement landscape dynamics in forests of the Pacific Northwest, USA. Forest Ecology and Management 85: 291-309.

Wedeles, C. and D.J.H. Sleep. 2008. Fragmentation in the boreal forest and possible effects on terrestrial wildlife. NCASI Technical Bulletin 2008(959): 1-69.

Wiersma, Y.F., P.N. Duinker, W. Haider, G.T. Hvenegaard and F.K.A. Schmiegelow. 2010. Relationships between Protected Areas and Sustainable Forest Management: Many Shades of Green. A State of Knowledge report. Sustainable Forest Management Network, Edmonton, AB. 58 p.

Wiersma, Y.F. and T.D. Nudds. 2009. Efficiency and effectiveness in representative reserve design in Canada: The contribution of existing protected areas. Biological Conservation 142(8): 1639-1646.

Witté, I. 2012. Toward complex forest management: Describing and measuring complexity in forests. Montreal, Université du Québec à Montréal, QC. $151 \mathrm{p}$.

Work, T.T., D.P. Shorthouse, J.R. Spence, W.J.A. Volney and D. Langor. 2004. Stand composition and structure of the boreal mixedwood and epigaeic arthropods of the Ecosystem Management Emulating Natural Disturbance (EMEND) landbase in northwestern Alberta. Canadian Journal of Forest Research 34(2): 417-430. 